\title{
Development of the all-vanadium redox flow battery for energy storage: a review of technological, financial and policy aspects
}

\author{
Gareth Kear, Akeel A. Shah ${ }^{* \dagger}$ and Frank C. Walsh \\ Electrochemical Engineering Laboratory, Energy Technology Research Group, School of Engineering Sciences, University of \\ Southampton, Highfield, Southampton SO17 1BJ, UK
}

\section{SUMMARY}

The commercial development and current economic incentives associated with energy storage using redox flow batteries (RFBs) are summarised. The analysis is focused on the all-vanadium system, which is the most studied and widely commercialised RFB. The recent expiry of key patents relating to the electrochemistry of this battery has contributed to significant levels of commercialisation in, for example, Austria, China and Thailand, as well as pilot-scale developments in many countries. The potential benefits of increasing battery-based energy storage for electricity grid load levelling and MW-scale wind/solar photovoltaic-based power generation are now being realised at an increasing level. Commercial systems are being applied to distributed systems utilising $\mathrm{kW}$-scale renewable energy flows. Factors limiting the uptake of all-vanadium (and other) redox flow batteries include a comparatively high overall internal costs of $\$ 217 \mathrm{~kW}^{-1} \mathrm{~h}^{-1}$ and the high cost of stored electricity of $\approx \$ 0.10 \mathrm{~kW}^{-1} \mathrm{~h}^{-1}$. There is also a low-level utility scale acceptance of energy storage solutions and a general lack of battery-specific policy-led incentives, even though the environmental impact of RFBs coupled to renewable energy sources is favourable, especially in comparison to natural gas- and diesel-fuelled spinning reserves. Together with the technological and policy aspects associated with flow batteries, recent attempts to model redox flow batteries are considered. The issues that have been addressed using modelling together with the current and future requirements of modelling are outlined. Copyright (c) 2011 John Wiley \& Sons, Ltd.

\section{KEY WORDS}

cost analysis; energy storage; redox flow battery; vanadium; energy policy; modelling

\section{Correspondence}

*A.A. Shah, Electrochemical Engineering Laboratory, Energy Technology Research Group, School of Engineering Sciences, University of Southampton, Highfield, Southampton SO17 1BJ, UK.

†E-mail: A.Shah@soton.ac.uk

Received 31 August 2010; Revised 18 March 2011; Accepted 15 April 2011

\section{INTRODUCTION}

Redox flow battery (RFB) technologies have demonstrated their ability to provide large-scale energy storage for applications including remote area power supplies (RAPS), back-up power supplies, distributed power generation and power quality optimisation. Although most of these applications are at the $\mathrm{kW}$ power scale, both MWand GW-scale stationary batteries have the potential to contribute to (1) improved energy efficiency and flexibility of national electricity grids, through load levelling/peak shaving, and (2) grid stabilisation of power derived from renewable energy-based sources (referred to in this paper as 'renewables') [1-6].

Load levelling via energy storage, rather than the use of a traditional combustion- (thermal) based spinning reserve, would involve distributed or utility-based sources of storage selling or transferring power to the grid during times of peak demand [7]. This approach can also increase the utility of renewables during periods of low demand and high generation and reduce or mitigate the requirement for peaking power (e.g. natural gas turbine-based) plants based on fossil fuels [5,7-10].

A major drawback of renewables is perceived to be grid instability at contribution levels greater than 20-30\%. This is because wind and photovoltaic (PV) power sources provide an intermittent supply from energy flows from the environment. Grid instability at a high percentage renewables could be especially prevalent in geographically limited countries, where a nation-wide distribution of renewables may not necessarily lead to favourable gridaveraged capacity during periods of widespread unfavourable weather [6]. The implementation of sufficient storage capacity, however, could enable renewables to be 
considered for base-load electricity supply and mitigate the need for a thermal-based spinning reserve.

Potentially beneficial energy storage technologies include enclosed and flow batteries (e.g. intelligent vehicle-to-grid traction battery systems or stationary distributed/utility-based systems $[7,9,10])$, pumped water, compressed air, thermal heating, high speed flywheels and hydrogen-based approaches [5-11]. Primary outcomes of energy storage could include energy efficiency improvements (and thus a reduction in the use fossil fuel-powered utilities) and an increased use of renewable energy sources.

The all-vanadium battery is the most widely commercialised RFB used for large-scale energy storage. It has a low environmental impact with regard to the environmental polluting potential of vanadium [12], especially when compared to traditional lead-acid batteries [13]. Past, present and potential future RFB competitors of the allvanadium battery include iron/chromium (NASA) [14], bromine/polysulphide (Regenesys) [15], zinc/bromine (ZBB) [16], zinc/cerium (Plurion) [17], and soluble leadacid batteries (University of Southampton) [18]. Many other variants of the half cells and the resultant cell chemistries are being developed internationally.

Although more traditional enclosed battery designs (e.g. sodium-sulphur technology) are being successfully applied to MW-scale stationary applications [6], the energy capacities of RFB systems could be considerably higher and the systems could be lower in cost, easier to operate and more flexible than enclosed systems [5-19]. For RFBs, a modular approach is also common, and generation capacity is directly proportional to the volume of electrolytes (conductive solution) stored externally to the battery housing, as shown in Figure 1. The power output and the rate of charge can also be varied as functions of the number of online battery stacks (consisting of subunits of individual electrochemical cells [5]).

With the global use of renewables increasing, the requirement for efficient, reliable and environmentally low impacting storage systems is being considered both at the intermediate scale $(\mathrm{kWh})$ and the large scale $(\mathrm{MW} \mathrm{h})$. For example, the all-vanadium battery has already been trialled or adopted commercially for load levelling and/or renewables support in Australia [20], Austria [21], Canada [22], Germany [23], China (PRoC) [24], the Republic of South Africa (RSA) [25], South East Asia [26], the United States of America (USA) [27], and, especially, Japan [28-30]. There is still a utility-scale knowledge gap at both the executive and technical levels, leading to a predisposition towards continued investment in fossil fuels to support the increasing levels of renewable energy generation (e.g. in New Zealand [31]).

In this paper, the development, history of commercialisation and current performance characteristics of intermediate- and large-scale and all-vanadium RFBs will be examined. The potential for the all-vanadium RFB system to meet the economic requirements of utilities will be compared with the economic performance of thermalbased generators through internal costs, operational and maintenance issues and the cost of environmental externalities (e.g., green house gas emissions, particulate emissions and health impacts [32]). National and international incentives that have been specifically applied to foster the development, cost-effectiveness and uptake of energy storage products will be reviewed for regions that have considered $\mathrm{kW}$ - to MW-power-rated RFB-based storage systems. The data will be assessed in terms of barrier identification at the distributed and electric utility levels and in terms of existing incentives in the field.

\section{THE ALL-VANADIUM REDOX FLOW BATTERY}

\subsection{Fundamental electrochemistry and performance characteristics}

With no solid phase changes, the all-vanadium flow cell, containing the $\mathrm{V}^{2+} / \mathrm{V}^{2+}$ (hypovanadous/vanadous ion) and $\mathrm{VO}^{2+} / \mathrm{VO}^{2+}$ (vanadyl/vanadic ion) redox couples, is comparatively simple and will operate with high-cell and stack-energy efficiencies. It is a dual electrolyte system where the separation of the redox couples is usually

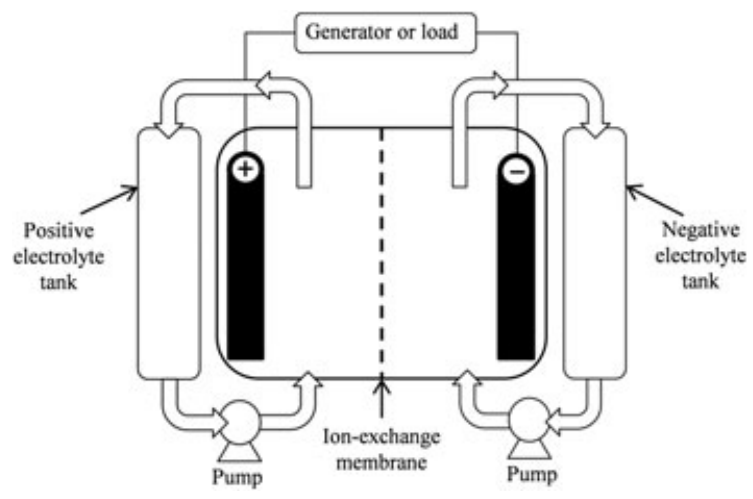

Figure 1. Schematic of the operation of a single cell, all-vanadium redox flow battery (regenerative fuel cell). The components are not drawn to scale. 
achieved using a cation (proton, $\mathrm{H}^{+}$) exchange membrane (Figure 2).

With a standard electrode potential $\left(E^{o}\right)$ of approximately $+1.00 \mathrm{~V}$ versus the standard hydrogen electrode (SHE), the characteristic reaction of the all-vanadium battery at the positive electrode, which involves soluble $\mathrm{V}$ (IV) and $\mathrm{V}(\mathrm{V})$ species, is as follows [5]:

$$
\mathrm{VO}^{2+}+\mathrm{H}_{2} \mathrm{O}-\mathrm{e}^{-} \underset{\text { Discharge }}{\stackrel{\text { Charge }}{\longrightarrow}} \mathrm{VO}_{2}^{+}+2^{\mathrm{H}+}
$$

The reversible reaction at the negative electrode involves $\mathrm{V}(\mathrm{II})$ and $\mathrm{V}$ (III) species and has a standard potential of $-0.26 \mathrm{~V}$ versus SHE:

$$
\mathrm{V}^{3+}+\mathrm{e}^{-} \underset{\text { Discharge }}{\stackrel{\text { Charge }}{\longrightarrow}} \mathrm{V}^{2+}
$$

Discharge of the cell is illustrated in Figure 2. The hypovanadous, vanadous, vanadyl and vanadic ions can be identified during operation of the cell by their colouration: violet, green, blue and light yellow, corresponding to soluble vanadium species in the (II), (III), (IV) and (V) oxidation states, respectively.

When the cell is overcharged, the side reactions of hydrogen and oxygen evolution can occur at the negative and positive electrodes, respectively:

$$
\begin{gathered}
2 \mathrm{H}^{+}+2 \mathrm{e}^{-} \rightarrow \mathrm{H}_{2} \\
2 \mathrm{H}_{2} \mathrm{O}-4 \mathrm{e}^{-} \rightarrow \mathrm{O}_{2}+4 \mathrm{H}^{+}
\end{gathered}
$$

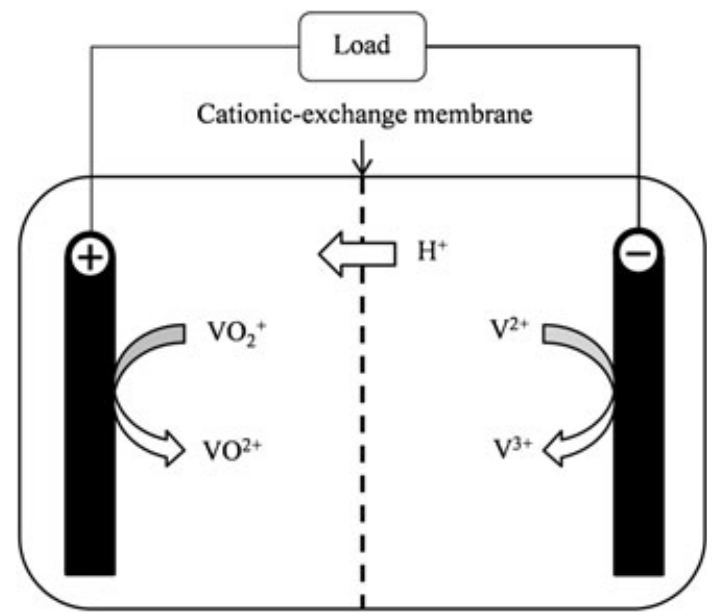

Figure 2. All-vanadium redox flow battery during discharge, illustrating the movement of protons through a cationic ionexchange membrane and electrons $\left(\mathrm{e}^{-}\right)$through the externa circuit. During discharge the positive and negatives electrodes are the cathode and the anode, respectively. During battery charge, the direction of the reactions and the movement of protons are reversed.
Gas evolution should be minimised because it can interrupt the electrolyte flow, lead to changes in the $\mathrm{pH}$, increase the cell resistance and, in the case of oxygen evolution, oxidise the carbon electrode (positive half cell).

The high cost of the electrolyte is one of the primary factors limiting the overall cost effectiveness of the vanadium battery $[9,33]$. Both the manufacture of electrolyte from the dissolution of vanadium pentoxide $\left(\mathrm{V}_{2} \mathrm{O}_{5}\right)$ in sulphuric acid and the optimisation of vanadyl sulphate $\left(\mathrm{VOSO}_{4}\right)$ solubility are non-trivial processes because the concentrations of the major species are dependent on the composition and temperature [34-38]. Electrolyte storage conditions must be controlled carefully to exclude air and to avoid decomposition of the charged electrolyte. There are also cost-based issues associated with the electrolyte feedstock [9] (as seen later in the cost analysis). A considerable number of vanadium-based electrolyte patents have been (or are still) active, and these tend to limit commercial applications without licence.

A low level of solute cross mixing and water transfer across the ion-exchange membrane is expected in practice and, therefore, a significant portion of the research effort has focused on improving the performance characteristics of the separator [39-43]. Although cross contamination does not pose a significant health hazard and the electrolytes can be regenerated by remixing, both regeneration and membrane durability are important considerations with regard to the operational efficiency, the operational and maintenance costs and the lifetime of the system. The electrolytes can also self-discharge if the pumps are allowed to run under open-circuit conditions. Only a single mole of electrons is exchanged for each mole of vanadium that is oxidised or reduced, and under normal operating temperatures, the maximum concentrations of $\mathrm{V}^{2+}$ and $\mathrm{V}^{3+}$ ions are limited to $\approx 2 \mathrm{~mol} \mathrm{dm}^{-3}$. Both of these factors effectively set a limit on the energy density of the cell $\left(25-35 \mathrm{Wh} \mathrm{kg}^{-1}\right)$ [5], which is relatively low in traction applications.

Despite these limitations, the theoretical (thermodynamic) standard cell voltage for the overall discharge reaction is favourable $(+1.26 \mathrm{~V})$ [44]. Excluding pumping costs, the energy density also has a reduced significance for stationary uses, especially if the infrastructure resources required for the establishment and operation of large-volume electrolyte reservoirs are readily available.

It is often claimed that the battery can be completely charged/discharged without detriment to subsequent cell performance. The rates of the electrochemical reactions are also usually reversible (rapid) on modified carbon-feltbased electrodes. High rates of reaction and favourable thermodynamics at low values of polarisation during charge and discharge lead to comparatively high charge, voltage and energy efficiencies $\left(\eta_{E}\right)$.

Typical RFBs consist of stacks of cells (Figure 3), fed by pumped electrolytes from large-capacity storage tanks. In this case, bipolar electrodes are normally used for each intervening cell in order to increase the cell voltage and current (power) rating. 


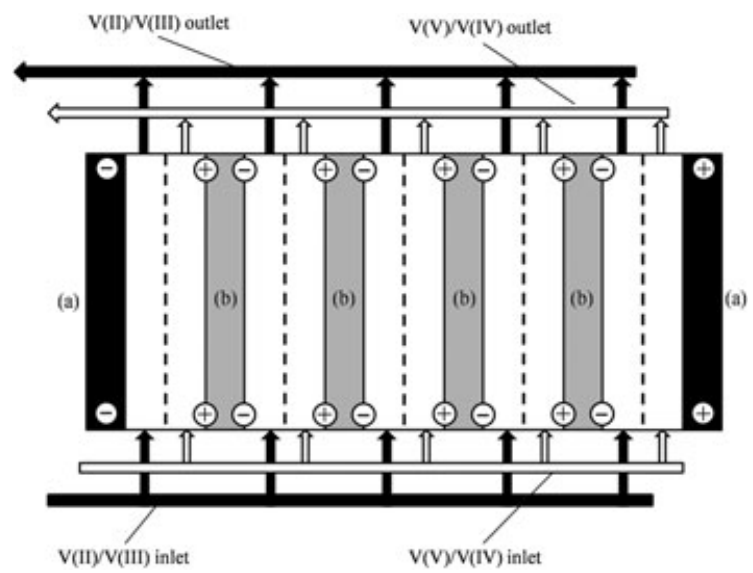

Figure 3. Schematic of a five-cell redox flow battery bipolar stack. (a) denotes the end plate monopolar electrodes, (b) bipolar electrodes and the broken line represents the ion-exchange membrane. The components are not drawn to scale.

A concise review of the technical developments in the all-vanadium battery, at commercial power-scales, is given in Table I. For these $\mathrm{kW}$-scale installations, the energy efficiencies of the cell processes are relatively high at $70-90 \%$. The energy efficiency of the overall system have been quoted as $80 \%$ or higher $[30,45]$. The pumping costs of standard designs, however, can consume $8-15 \%$ of the overall energy. In practice, energy efficiencies of $60-65 \%$ are common.

Current (charge/coulombic) efficiency values of $98 \%$, have been calculated for the all-vanadium flow cell, compared with $80-90 \%$ and $81-99 \%$ for the lead-acid enclosed cell and the iron/chromium flow cell, respectively $[5,46]$. The energy efficiency of the all-vanadium battery is lower than that of the lead-acid battery $(<90 \%)$ [46], but a voltage efficiency of around $70 \%$ is within the range of typical values measured for RFBs using the iron/ chromium (73-82\%) [47,48] and bromine/polysulfide (75\%) [49] couples.

\subsection{The pathway to commercialisation and incentives for development}

At the $\mathrm{kW}$ to MW scales, research and development (Table I) driving the commercialisation of vanadium-based flow cells over the last two decades has significantly improved efficiencies, lowered the capital and operational costs and improved material durability. Early work on the RFB was published by the National Aeronautics and Space Administration (NASA), USA in the 1970s [19]. Soon afterwards, vanadium redox couples were considered for both chemically [59] and electrochemically regenerative (electrically re-chargeable) flow batteries [44] and during the 1980s a number of patents discussing the use of vanadium-based species in RFBs were filed in the USA and elsewhere [14,60-62].

An early programme of research into RFBs was presented in 1982 by Oei of the Ford Motor Company,
USA, examining the $\mathrm{VO}^{2+} / \mathrm{VO}_{2}^{+}$redox couple at the positive electrode and $\mathrm{Cu} / \mathrm{Cu}^{2+}, \mathrm{Fe}^{2+} / \mathrm{Fe}^{3+}$ or $\mathrm{Sn}^{2+} / \mathrm{Sn}^{4+}$ couples at the negative electrode [63]. Additional work was also performed using this positive half-cell electrolyte with the $\mathrm{SiW}_{12} \mathrm{O}_{40}^{5-} / \mathrm{SiW}_{12} \mathrm{O}_{40}^{4-}$ couple [64]. In July of 1984, a paper describing an all-vanadium cell exploiting a $\mathrm{V}^{2+} / \mathrm{V}^{3+}$ negative half-cell electrolyte was submitted by Kummer and Oei [65].

The all-vanadium cell addressed a significant problem of electrolyte cross contamination in mutli-component cells (although, as discussed earlier, the transfer of vanadium species through the membrane would continue to occur). The battery utilised concentrated sulphuric acidbased electrolytes, which, when regenerated (charged), were able to discharge at a maximum power density output of $0.0745 \mathrm{~W} \mathrm{~cm}^{-2}$ at a cell voltage of $+0.98 \mathrm{~V}$.

Kummer and Oei were quick to conclude that (1) the relatively low molar mass of the vanadium species would be advantageous for pumping if applied to stationary flow cells (in relation to viscosity-based energy losses) and (2) that electrolytic regeneration could provide a viable battery system.

In 1985, Sum, Rychcik and Skyllas-Kazacos published the results of an investigation into the direct application [66] of the $\mathrm{V}^{2+} / \mathrm{V}^{3+}$ and [67] $\mathrm{VO}^{2+} / \mathrm{VO}_{2}^{+}$redox couples to flow batteries, also using sulphuric acid-based electrolytes. Subsequently, full patents for the all-vanadium battery were filed in Australia [68] and the USA [61] with Unisearch Limited, University of New South Wales (UNSW) Australia as the applicant. These primary patents expired in 2006, leading to a renewed interest on the commercialisation of the technology.

Since the 1980s, a number of developments in the allvanadium battery have taken place either at UNSW or its collaborators, or in Austria, Canada, Japan, the PRoC and Thailand. Unisearch licences were granted to Thai Gypsum in Thailand (1993) to develop and exploit the technology for residential housing-based PV applications; 
Table I. Summary of technical literature on performance of the all-vanadium redox flow battery at the $1 \mathrm{~kW}$ - to $1 \mathrm{MW}$-scale. $\eta_{\mathrm{E}}=$ energy efficiency of flow battery stack; $\eta_{\text {system }}=$ total system power efficiency.

\begin{tabular}{|c|c|c|c|c|c|}
\hline Author/s & $\eta_{\mathrm{E}}$ & Power & Energy & Country & Funding body \\
\hline $\begin{array}{l}\text { Rychicik and Skyllas-Kazacos } \\
\text { (1988) [50] }\end{array}$ & Not stated & $1 \mathrm{~kW}$ & $5 \mathrm{kWh}$ & Australia & $\begin{array}{l}\text { Australian Department of } \\
\text { Resources and Energy }\end{array}$ \\
\hline $\begin{array}{l}\text { Skyllas-Kazacos et al. } \\
\text { (1991) [51] }\end{array}$ & $72-90 \%$ & $1.33 \mathrm{~kW}$ & $\begin{array}{l}0.7 \mathrm{kWh} \\
\quad(40-42 \mathrm{Ah})\end{array}$ & Australia & $\begin{array}{l}\text { Australian National Energy } \\
\text { Research Development } \\
\text { Council, NSW Department of } \\
\text { Minerals \& Energy and Mount } \\
\text { Resources Ltd. }\end{array}$ \\
\hline Largent et al. (1993) [26] & Not stated & $1.6-5 \mathrm{~kW}$ & $12 \mathrm{kWh}$ & Australia & $\begin{array}{l}\text { Australia Research Council, Pacific } \\
\text { Power, NSW Office of Energy } \\
\text { and Thai Gypsum Co. Ltd. }\end{array}$ \\
\hline $\begin{array}{l}\text { Skyllas-Kazacos and } \\
\text { Menictas (1997) [3] }\end{array}$ & $>80 \%$ & $1-3 \mathrm{~kW}$ & Not stated & Australia & Unisearch Ltd. \\
\hline \multirow{5}{*}{$\begin{array}{l}\text { Itoh et al. and Tokuda et al. } \\
\text { (1999 and 2000, } \\
\text { respectively) [30,45] }\end{array}$} & $\eta_{E}=80 \%$ & $\approx 20 \mathrm{~kW}$ & $\approx 10 \mathrm{~kW} \mathrm{~h}(0.5 \mathrm{~h})$ & \multirow[t]{5}{*}{ Japan } & \multirow{5}{*}{$\begin{array}{l}\text { Sumitomo Electric Ltd. and The } \\
\text { Kansai Electric Power Co., Inc. }\end{array}$} \\
\hline & $80-85 \%$ & $50 \mathrm{~kW}$ & $175-400 \mathrm{kWh}$ & & \\
\hline & $\begin{array}{l}\eta_{\text {system }}= \\
\quad 80-85 \%\end{array}$ & & & & \\
\hline & $75-82 \%$ & $450 \mathrm{~kW}$ & 900 kWh (2 h) & & \\
\hline & $\eta_{\text {system }}=70 \%$ & & & & \\
\hline Shibata and Sato (1999) [52] & Not stated & $200 \mathrm{~kW}$ & 800 kWh (4h) & Japan & Kashima-Kita Electric Power Corp. \\
\hline $\begin{array}{l}\text { Miyake and Tokuda } \\
\text { (2001) [53] }\end{array}$ & Not stated & Not stated & $30-3 \mathrm{MWh}$ & Japan & $\begin{array}{l}\text { Sumitomo Electric Ltd. and The } \\
\text { Kansai Electric Power Co., Inc. }\end{array}$ \\
\hline $\begin{array}{l}\text { Various commercial batteries } \\
\text { (2002) [54] }\end{array}$ & Not stated & 10 to $50 \mathrm{~kW}$ & Not stated & Thailand & $\begin{array}{l}\text { Cellennium (Thailand) Company } \\
\text { Ltd. }\end{array}$ \\
\hline $\begin{array}{l}\text { Hawkins and Robbins } \\
\text { (2002) [25] }\end{array}$ & $82-85 \%$ & $250 \mathrm{~kW}$ & $520 \mathrm{~kW} \mathrm{~h}$ & $\begin{array}{l}\text { Australia/ } \\
\text { Canada }\end{array}$ & $\begin{array}{l}\text { Telepower Australia Pty. and } \\
\text { Vanteck (VRB) Technology } \\
\text { Corp. }\end{array}$ \\
\hline $\begin{array}{l}\text { Shigematsu et al. } \\
\text { (2002) [2] and }\end{array}$ & Not stated & $\begin{array}{l}1.5 \mathrm{MW}- \\
3 \mathrm{MW}(1.5 \mathrm{~s})\end{array}$ & $\begin{array}{l}3600- \\
7200 \mathrm{MWh}(1.5 \mathrm{~s})\end{array}$ & Japan & Sumitomo Electric Ltd. \\
\hline Shinzato et al. (2002) [55] & Not stated & $170-275 \mathrm{~kW}$ & Not stated & & \\
\hline Skyllas-Kazacos (2002) [56] & Not stated & Not stated & $3.9 \mathrm{kWh}$ & Australia & Not stated \\
\hline Schreiber et al. (2005) [1] & Not stated & $1 \mathrm{~kW}$ & $50 \mathrm{kWh}$ & Austria & $\begin{array}{l}\text { ASFINAG (Austrian Motor and } \\
\text { Expressway Operator) }\end{array}$ \\
\hline \multirow[t]{2}{*}{ Zhao et al. (2006) [57] } & $77-78 \%$ & $\begin{aligned} \approx & 1 \mathrm{~kW} \\
& (0.7-1.4 \mathrm{~kW})\end{aligned}$ & Not stated & \multirow[t]{2}{*}{ PRoC } & \multirow[t]{2}{*}{ National 863 Programme of China } \\
\hline & $80-82 \%$ & $\begin{array}{l}\approx 10 \mathrm{~kW} \\
\quad(5-10 \mathrm{~kW})\end{array}$ & $0.1 \mathrm{Wh} \mathrm{cm}^{-2}$ & & \\
\hline Huang et al. (2008) [24] & Not stated & $0.25-0.9 \mathrm{~kW}$ & $24 \mathrm{Whdm}^{-3}$ & PRoC & $\begin{array}{l}\text { Pan-tang Group Pang-zhi-hua Iron } \\
\text { and Steel Research Institute }\end{array}$ \\
\hline $\begin{array}{l}\text { Various commercial } \\
\text { batteries [28] }\end{array}$ & Not stated & $\begin{array}{l}80-150 \mathrm{~W} \mathrm{~kg}^{-1} \\
\text { electrolyte }\end{array}$ & $2.5-10 \mathrm{MWh}$ & Canada & VRB Power Systems Inc. \\
\hline
\end{tabular}

small-scale field testing of PV-based RAPS systems was initially performed in partnership with UNSW [26]. This stage of the all-vanadium battery development at UNSW was supported by both by the Australian government (National Energy Research, Development and Demonstration Council, Energy Research and Development Corporation, New South Wales Office of Energy and Australian Research Council) and commercial entities, (e.g., Pacific Power, Australia, and Thai Gypsum Co., Thailand [26]). Currently, the all-vanadium technology is marketed largely outside Australia (in Australia, the focus of the research has shifted to the vanadium/bromine ( $\mathrm{VBr}$ ) battery, which is being commercialised through V-Fuel
Pty. Ltd. ${ }^{\ddagger}$ A recent review of activity at UNSW can be found in [69]).

In 1993, Unisearch also licensed Mitsubishi International Corporation (MIC) and Kashima-Kita Electric Power Corporation for battery load-levelling and PV-development applications. In 1998 Pinnacle VRB (Australia) acquired the technology from Unisearch and licensed the battery to

\footnotetext{
${ }^{\ddagger}$ V-Fuel is licensed by Unisearch Ltd., New South Wales, Australia, and has been supported by capital investment from the Victorian Government-funded, Centre for Energy and Greenhouse Technologies Pty Ltd.
} 
Sumitomo Electric Industries (SEI), for use in Japan (1999), and to VRB Power Systems, Inc. in Canada (Vanteck VRB Technology Corporation) for deployment in North America and Africa.

VRB Power Systems marketed an all-vanadium battery for RAPS, emergency power supply and $\mathrm{kW}$-scale to MWscale load-levelling and renewables support [10]. In 2004, VRB Power purchased a licence to the 'Innogy' technology, developed by Regenesys in the UK and based on the bromine/polysulphide RFB (total $\$ 1.3$ million). VRB Power thus acquired the rights to the Regenesys flow-frame designs, assembly equipment and cell apparatus, which was equally applicable to the all-vanadium cell [70] (all interests in the Regenesys RFB system were owned at the time by Rheinisch-Westfälisches Elektrizitätswerk (RWE) and npower Plc., Germany/UK). In 2005, VRB Power also acquired the commercial rights to vanadium battery technologies owned by SEI.

VRB Power manufactured and installed the VRB-ESS (vanadium redox battery-energy storage system) range of batteries, which had a typical discharge-charge range of $20-80 \%$. An overall efficiency of $65-70 \%$ was claimed for more than 10000 cycles [71]. The company is believed to have sourced vanadium from Highveld Steel and Vanadium Corporation in the RSA (a subsidiary of UK-based, Anglo-Amercian).

VRB Power continued to market the vanadium redox battery energy storage system until February 2009, when all VRB Power assets were sold to Prudent Energy Inc. (J.D. Holdings, PRoC) [72]. Prior to this sale, VRB Power was promoting the success of two $\mathrm{kW}$-scale installations $[71,73]$. The first was the Utah Power (a subsidiary of PacifiCorp) operated VRB-ESS in Castle Valley, USA $(250 \mathrm{~kW}, 2 \mathrm{MW}$ h) for load levelling, which was installed in November 2004. The second installation was on the Huxley Hill wind farm operated by Hydro Tasmania, supplementing diesel generation on King Island off the Australian coast (2003). The energy capacity of the latter is $1.1 \mathrm{MW} \mathrm{h}$ with a continuous power rating of $200 \mathrm{~kW}$ for $4 \mathrm{~h}$. Peak short-term output is claimed to be $400 \mathrm{~kW}$ for $10 \mathrm{~s}$ or $300 \mathrm{~kW}$ for $5 \mathrm{~min}$. The Australian project was financially supported by the Australian Greenhouse Office.

As previous licensees to Unisearch and Pinnacle, both Mitsubishi Corporation and the Sumitomo Electric
Corporation invested in all-vanadium-based RFB technologies for application in Japan (Table I). Mitsubishi, (via The Kansai Electric Power Corp. Inc.) installed and trialled a $20 \mathrm{~kW}$ all-vanadium battery at Kashima Kita Power Station, which led to the operation of a $200 \mathrm{~kW}$ (4h) installation at this location in 1997 [52]. Mitsubishi passed on the licence to Sumitomo and since 2003 have invested in partnership with Cellennium (Thailand) Company Limited [74].

Sumitomo have trialled batteries for $\mathrm{kW}$ - to MW-scale load levelling and power quality applications in office buildings, universities and semiconductor factories (Table II) and some details of the technical development have been published (Table I). As of 2008, SEI had approximately sixteen VRB systems operating in Japan for applications including load levelling, power quality maintenance and energy storage associated with renewables.

A recent practical example is the $6 \mathrm{MW} \mathrm{h}$ all-vanadiumflow battery system installed at the $30 \mathrm{MW}$ wind farm in Sapporo, Japan [7] (Table II). In total, Japan now has a battery storage capacity equivalent to approximately $250 \mathrm{MW}$, used in load levelling, power quality and renewable energy applications [6]. A recently developed windfarm battery storage facility incorporating an enclosed 34 MW sodium-sulphur battery energy storage facility is supported by both a government investment subsidy and a nationwide lead-in tariff for renewables $(¥ 20 \quad[\approx \$ 0.2]$ $\mathrm{kW}^{-1} \mathrm{~h}^{-1}$ added to the market price of electricity).

Leading up to the acquisition of VRB Power by Prudent (a private company, backed by USA-derived venture capital), a significant amount of all-vanadium battery research was conducted in the PRoC. Details can be found in publications discussing PRoC-derived developments on ion-exchange membrane performance [24,75] electrode materials/activity [76,77] and electrode processes [78,79] from institutions including Tsing Hua University, the Chinese Academy of Sciences, Central South University of Technology, Peking University, University of Science and Technology, Beijing, and South China Normal University. Prudent is promoting itself as a global supplier of stationary energy storage solutions and has retained the original VRB Power offices in Canada under the trading name of Prudent Energy International.

Table II. Examples of the kW- to MW-scale of operation of all-vanadium redox flow batteries in Japan installed by Sumitomo Electric Industries. Table modified and expanded from Grimm [7].

\begin{tabular}{|c|c|c|c|c|c|}
\hline Situation & Application & Power/kW & Energy/kWh & Duration/h & Date of first operation \\
\hline Wind farm [10] & Voltage quality & 4000 & 6000 & 1.5 & 2007 \\
\hline \multirow[t]{2}{*}{ Semiconductor factory } & (i) Voltage droop protection & (i) 3000 & (i) 75000 & (i) 0.0004 & April 2004 \\
\hline & (ii) Load levelling & (ii) 1500 & (ii) 1500 & (ii) 1 & \\
\hline Office building & Load levelling & 100 & 800 & $8 \mathrm{~h}$ & February 2002 \\
\hline University & Load levelling & 500 & 5000 & 10 & July 2001 \\
\hline Wind turbine & Stabilisation of turbine output & 170 & 1020 & 6 & April 2001 \\
\hline Golf course & Load levelling of PV system & 30 & 240 & 8 & April 2001 \\
\hline
\end{tabular}

PV, photovoltaic. 
With regard to the domestic market in the PRoC, Prudent is intending to supplement the huge governmentbacked growth in MW-scale solar photovoltaic and wind power generation technologies in the PRoC. Because Prudent states that at peak consumption the electricity grids of many of the major cities in the PRoC are operating at greater than $95 \%$ capacity [8], the company is also promoting city-focused load levelling and voltage spike protection. Therefore, the all-vanadium battery could be an effective method for reducing the burden on the electricity supply system in the country, at least in the short term. The company does admit, however, that production rates are limited by issues associated with the manufacture of the vanadium electrolyte and that research is continuing in this area [33]. The company strategy for 2009 seeks to 'improve on the efforts of VRB Power by reducing the costs of the technology and expanding its markets', enabled by 'significant cost reductions and production enhancements'.

In Europe, the lack of investment in load levelling, power quality and grid-connected renewable energybattery applications may be, at least in part, due to the relatively efficient, nationally interconnected, high voltage transmission system [6]. This grid can geographically average the intermittency of supply and reduce the risk associated with losses in regional power generation capacity. In both Germany and Austria, on the other hand, there is interest in applying energy storage technologies to regulate intermittent renewable energy supply [7,9]. In Austria, Cellstrom GmbH (established 2002) is now marketing an all-vanadium battery design for distributed energy and voltage output moderation from PV and windbased renewables [21]. Production of a $100 \mathrm{kWh}$ capacity flow battery $(10 \mathrm{~kW} ; 10 \mathrm{~h})$ began in 2008 , for sale within Europe only [80]. The power rating of this battery may be suitable for remote communications, radar, diary and electric vehicle charging installations [81]. In the context of distributed energy sources, this product is aimed at servicing structures that are the size of apartment blocks and small commercial installations. The $100 \mathrm{kWh}$ energy capacity of the standard unit is more than sufficient to meet the demand of typical houses in Europe, which consume $\approx 8$ to $12 \mathrm{~kW} \mathrm{~h} \mathrm{day}^{-1}$ ( 3 to $5 \mathrm{~kW} \mathrm{~h} \mathrm{day}^{-1}$ for an efficient offgrid house with gas cooking and heating) [82].

In the UK, the promising and extensively researched bromine/polysulfide RFB (Regenesys Technology) planned for Little Barford, South England (15 MW, $120 \mathrm{MW} \mathrm{h}$ ) was terminated in December 2003 [5]. RFB work is continuing in the UK with, for example, Re-Fuel Technology (Re-Fuel ESD). Re-Fuel has adopted an allvanadium-based battery, which was originally developed with funding from the former UK Department of Trade and Industry. The company has led a research and development project funded by the Technology Strategy Board (UK government) as part of a consortium that included the University of Southampton, UK and Scottish Power, UK. Re-Fuel was launched in 2003 [83] and has designed and operated a $5 \mathrm{~kW}(6-12 \mathrm{~h})$ pilot-scale stack containing 40 bipolar electrodes.
A $1.5 \mathrm{MW}, 8 \mathrm{~h}, 12 \mathrm{MWh}$ all-vanadium VRB-ESS has been proposed for installation at the $38 \mathrm{MW}$ Sorne Hill Wind farm in County Donegal, Ireland (operational 2006). This storage facility was reported to have the potential to realise 2.0 MW [84] and has been jointly commissioned by Sustainable Energy Ireland and Tapbury Management Limited. Sustainable Energy Ireland is a governmentfunded organisation supplying investment capital from the National Development Plan 2007-2013, partly financed by the European Union [85]. Investment in the wind farm is a direct result of the Irish government's target of electricity from renewables, the majority of which will have to be met by wind power.

Interest in large-scale battery applications in the USA has included feasibility studies, such as that for Boulder City [86]. The only development of any significance is the 2 MW h VRB-ESS installation for Utah. This load levelling unit was the first installation of its kind in the USA [9]. ZBB Energy Corp. (Wisconsin, USA/Perth, Australia) have since commercialised the zinc/bromine RFB [16] as two energy classes: $50 \mathrm{~kW} \mathrm{~h}$ and $500 \mathrm{~kW} \mathrm{~h}(250 \mathrm{~W}, 2 \mathrm{~h})$ [87]. These batteries have energy conversion efficiencies of around $70 \%$. MW-scale ZBB RFBs are not currently in use in the USA, although relatively small-scale ZBB units have been used; for example, by Pacific Gas and Electric Company (San Francisco, USA), Detroit Edison (Detroit, USA), and Sandia National Laboratories (Albuquerque, USA) [87].

In Thailand, Cellennium completed a set of technology licensing agreements for a novel battery flow system from Squirrel Holdings Limited in 2002 [74,88]. With investments from Mitsubishi (2003) and the Royal Thailand Government (2008), via MFC Asset Management Plc., the company has now initiated full-scale production of $\mathrm{kW}$-scale all-vanadium batteries. Ten million US dollars came from the MFC's Energy Fund, which provides targeted investments in renewable energy sources. The Squirrel technology was originally patented in 1978 [62] and uses an all-vanadium electrolyte. The company has reported that the novel flow system of this battery allows pumping losses to be reduced significantly (1\% of total power converted). The Cellennium stack appears to sit vertically, rather than horizontally and utilizes a oncethrough discharge process. The Cellennium system is now promoted in Thailand for residential to village-sized energy storage power output (10 to $100 \mathrm{~kW})$, which is usually associated with solar PV and biomass energy sources.

In 2003, Cellennium also received a concession from the Thailand Ministry of Energy to commercially trade electricity with the grid from a vanadium battery associated with a net metered solar PV system [89]. The system has allowed sales of electricity to the Metropolitan Electricity Authority (MEA) since early 2004. This concession was awarded under a policy enacted in 2002 to support small-scale ( $\leq 1 \mathrm{MW}$ ) producers that utilise renewable energy sources. Thailand has also adopted a feed-in policy for wind, solar, biomass and micro-hydro 
[90], much of which could stimulate further uptake of the Cellennium battery system in the region.

\section{COST ANALYSIS}

It has to be stressed that a wide variety of costs have been considered for all-vanadium RFBs and costs often reflect development costs. Access to the commercial costs of flow batteries is limited and the costs are place- and timedependent. The typical capital costs of manufacture of a $2 \mathrm{~kW} / 30 \mathrm{kWh}$ all-vanadium RFB have been estimated by Jörissen of Zentrum Sonnenenergie und Wasserstoff Forschung (ZSW), Germany and subsequently reviewed by Jossen and Sauer in 2006 (Table III) [9]. The materials costs associated with the cell manufacture were $€ 2,315$ $(\approx \$ 3,200)$ or $€ 1,157 \mathrm{~kW}^{-1}\left(\approx \$ 1,600 \mathrm{~kW}^{-1}\right)$. The energy storage capital costs were $€ 2350(\approx \$ 3,300)$ or $€ 78 \mathrm{~kW}^{-1}$ $\mathrm{h}^{-1}\left(\approx \$ 100 \mathrm{~kW}^{-1} \mathrm{~h}^{-1}\right)$. The overall internal cost is $\approx \$ 3,300 \mathrm{~kW}^{-1}$. Jossen and Sauer estimated that $1 \mathrm{~kW}$ to $100 \mathrm{MW}$ scale all-vanadium-based storage systems were economically feasible for specific applications. Moreover, unlike enclosed batteries, the authors considered that the economic favourability of RFBs increases dramatically with nominal energy capacity. It was considered, however, that a number of issues of cost and supply must be overcome, in particular those relating to the electrolyte materials ( $€ 48[\approx \$ 70] \mathrm{kW}^{-1} \mathrm{~h}^{-1}$ ), historical fluctuations in the cost of typical vanadium feedstocks $\left(\mathrm{V}_{2} \mathrm{O}_{5}\right.$ and $\left.\mathrm{FeV}\right)$ and the electrolyte manufacturing process itself. MW-scale systems require installation in warehouse-sized structures, but the above costs do not consider infrastructure needs and the additional cost of integration into the grid/ distributed power supply system.

VRB Power also presented a cost analysis for their battery [91] in terms of the installed energy storage capacity. For an eight month installation period, the estimated range of capital costs (excluding infrastructure/ grid integration) was $\$ 350$ to $\$ 600 \mathrm{~kW}^{-1} \mathrm{~h}^{-1}$ (100 kW to MW scale). An average cost of $\$ 500 \mathrm{~kW}^{-1} \mathrm{~h}^{-1}$ may be assumed. This cost is likely to reduce as the scale of stored energy is increased.

The time to first service of the VRB Power system is dependent on the life expectancy of the membrane, which was guaranteed for 10 years. Cellstrom [82] also currently present a 10-year time to first service, at which point, membrane replacement and other material costs are estimated to be approximately $15 \%$ of the cost of the original purchase price.

Table IV gives typical cost components of electricity for a selection of fossil fuel and renewable-power generation [92]. Overnight costs represent the installed capacity per $\mathrm{kW}$, and the variable operational and maintenance costs are scalable with a dependency on the output. The heat rate describes the efficiency of the power plant in terms of energy consumed relative to generation.

Table III. Estimated internal capital costs associated with a $2 \mathrm{~kW} / 30 \mathrm{~kW}$ h all-vanadium redox flow battery. Table modified from an approach by Jossen and Sauer [9].

\begin{tabular}{|c|c|c|c|}
\hline & Value & Cost per unit & Total cost \\
\hline \multicolumn{4}{|l|}{ System data } \\
\hline Mean current density & $52 \mathrm{~mA} \mathrm{~cm}^{-2}$ & - & - \\
\hline Electrode area & $1.75 \mathrm{~m}^{2} \mathrm{~kW}^{-1}$ & - & - \\
\hline $\mathrm{V}_{2} \mathrm{O}_{5}$ equivalent energy & $6.0 \mathrm{~kg} \mathrm{~kW}^{-1} \mathrm{~h}^{-1}$ & - & - \\
\hline \multicolumn{4}{|l|}{ Flow cell costs } \\
\hline Activated carbon-felt electrode & $3.5 \mathrm{~m}^{2} \mathrm{~kW}^{-1}$ & $€ 50 \mathrm{~m}^{-2}\left(\$ 70 \mathrm{~m}^{-2}\right)$ & $€ 350(\$ 490)$ \\
\hline Bipolar current collector & - & $€ 65 \mathrm{~kW}^{-1}\left(\$ 91 \mathrm{~kW}^{-1}\right)$ & $€ 130(\$ 182)$ \\
\hline Frame and associated components & - & $€ 435 \mathrm{~kW}^{-1}\left(\$ 609 \mathrm{~kW}^{-1}\right)$ & $€ 870(\$ 1218)$ \\
\hline Ion-exchange membrane & $2.1 \mathrm{~m}^{2} \mathrm{~kW}^{-1}$ & $€ 25 \mathrm{~m}^{-2}\left(\$ 35 \mathrm{~m}^{-2}\right)$ & $€ 105(\$ 147)$ \\
\hline Electrolyte storage tanks $(\times 2)$ & $550 \mathrm{dm}^{3}$ (each) & $€ 185$ each (\$259 each) & $€ 370(\$ 518)$ \\
\hline Pumps (x 2) & - & $€ 160$ each (\$224 each) & $€ 320(\$ 448)$ \\
\hline Control system & - & $€ 500(\$ 700)$ & $€ 500(\$ 700)$ \\
\hline Total flow cell cost & - & - & $\begin{array}{l}€ 2315(\$ 3241) \\
€ 1157 \mathrm{~kW}^{-1}\left(\$ 1620 \mathrm{~kW}^{-1}\right)\end{array}$ \\
\hline \multicolumn{4}{|l|}{ Storage costs } \\
\hline $\mathrm{V}_{2} \mathrm{O}_{5}$ (solute) & $180 \mathrm{~kg}$ & $€ 8.0 \mathrm{~kg}^{-1}\left(\$ 11 \mathrm{~kg}^{-1}\right)$ & $€ 1440(\$ 2016)$ \\
\hline Electrolyte manufacture & - & $€ 3.0 \mathrm{~kg}^{-1}\left(\$ 4 \mathrm{~kg}^{-1}\right)$ & $€ 540(\$ 756)$ \\
\hline Tanks & $550 \mathrm{dm}^{3}$ (each) & $€ 185$ each (\$259 each) & $€ 370(\$ 518)$ \\
\hline Total storage costs & - & - & $\begin{array}{l}€ 2350(\$ 3290) \\
€ 78 \mathrm{~kW}^{-1} \mathrm{~h}^{-1} \\
\left(\$ 109 \mathrm{~kW}^{-1} \mathrm{~h}^{-1}\right)\end{array}$ \\
\hline Overall internal cost & - & - & $\begin{array}{l}€ 4665(\$ 6531) \\
€ 155 \mathrm{~kW}^{-1} \mathrm{~h}^{-1} \\
\left(\$ 217 \mathrm{~kW}^{-1} \mathrm{~h}^{-1}\right)\end{array}$ \\
\hline
\end{tabular}


Table IV. Typical cost components of electricity generation from natural gas-based technologies (costs reflect 2002 market status and penetration), after Kammen [92].

\begin{tabular}{|c|c|c|c|}
\hline Technology & Overnight costs $/ \$ \mathrm{~kW}^{-1}$ & $\begin{array}{l}\text { Variable operational and } \\
\text { maintenance costs } / \$ \mathrm{~kW}^{-1} \mathrm{~h}^{-1}\end{array}$ & Heat rate $/ \mathrm{MJ} \mathrm{kW}^{-1} \mathrm{~h}^{-1}$ \\
\hline Conventional gas/oil combined cycle & 542 & 0.002 & 8 \\
\hline Advanced gas/oil combined cycle (ADVCC) & 615 & 0.002 & 7 \\
\hline ADVCC with carbon sequestration & 615 & 0.002 & 7 \\
\hline Conventional combustion turbine & 413 & 0.004 & 11 \\
\hline Advanced combustion turbine & 466 & 0.003 & 10 \\
\hline Fuel cell & 2162 & 0.021 & 8 \\
\hline Wind power & 1015 & 0.000 & 11 \\
\hline Solar PV & 4401 & 0.000 & 11 \\
\hline
\end{tabular}

PV, photovoltaic.

The overnight cost of an advanced combustion turbine is around $\$ 470 \mathrm{~kW}^{-1}$, which is considerably more favourable than the analysis of Jörissen, albeit at a much higher power rating. There is no fuel component for a battery, although the operation and maintenance costs of a VRB-ESS, as estimated by VRB Power, are rather high, at approximately [58] $\$ 0.008 \mathrm{~kW}^{-1} \mathrm{~h}^{-1}$. In comparison, the operation and maintenance costs of advanced gas/oil combined cycles are only $\$ 0.003 \mathrm{~kW}^{-1} \mathrm{~h}^{-1}$ (Table IV). There are, however, additional turbine fuel costs $\left(\$ 0.03-0.08 \mathrm{~kW}^{-1} \mathrm{~h}^{-1}\right)$, and such costs are also subject to market fluctuations. Excluding external costs, the cost of electricity from natural gas combined cycle turbine technology is around [93] $\$ 0.05-0.06 \mathrm{~kW}^{-1} \mathrm{~h}^{-1}$. The current price of wind power from an onshore 1-3 MW turbine can be higher $\left(\$ 0.05-0.08 \mathrm{~kW}^{-1} \mathrm{~h}^{-1}\right)$ [90], although the cost of environmental externalities is likely to be considerably lower.

Taking the cost of Jörissen for a small $2 \mathrm{~kW} / 30 \mathrm{kWh}$ installation (as shown in Table III), the implementation of such flow battery may lead to an amortised capital cost of $\$ 850$ and a cost of stored electricity of ${ }^{\S} \$ 0.10 \mathrm{~kW}^{-1} \mathrm{~h}^{-1}$. When the cost of electricity from wind power is added to the energy storage cost to give a total combined generation/storage cost of $\$ 0.15-0.18 \mathrm{~kW}^{-1} \mathrm{~h}^{-1}$, this simple economic analysis indicates a rather unfavourable price comparison relative to a fossil fuel-based spinning reserve, even though the analysis is generally biased towards favouring the battery-wind turbine generationstorage system.

Experience curves for the pricing of emerging energy technologies (e.g. wind turbines [94]) show that post acceptance of the technology, the prices of such batteries are likely to decrease rapidly in the short term as a consequence of reductions in the manufacturing, operational

\footnotetext{
${ }^{\S}$ The analysis assumes operation and maintenance costs of $\$ 0.008 \mathrm{~kW}^{-1} \mathrm{~h}^{-1}$, a generous battery capacity factor of $50 \%$, zero fuel costs, the exclusion of housing infrastructure costs, grid connection and a capital recovery factor of 0.13 at a $5 \%$ interest rate for a 10-year battery life expectancy.
}

and maintenance costs. It may also be assumed that current batteries operating at a maximum of $75 \%$ energy efficiency (Table I) will be superseded by systems with higher efficiencies. Environmental externality cost estimates of electricity generation from the combustion of natural gas typically range from [95] $€ 0.010$ to $€ 0.024$ ( $\$ 0.014$ to $\$ 0.034) \mathrm{kW} \mathrm{h}^{-1}$ in the European Union (EU). Base-load generation from renewable energy flows combined with battery storage is likely to result in considerably lower externality costs, because of the mitigation of $\mathrm{CO}_{2}, \mathrm{NO}_{\mathrm{x}}$ and hydrocarbon emissions.

The economic and environmental benefits of the allvanadium battery installed at King Island in 2003 were estimated by VRB Power and are summarised in Table V. This simple, non-annuitised economic analysis yielded an estimated 3.5 year payback period for the return of the capital investment in terms of reducing operational costs relative to the running of a diesel-fuelled generator [73]. Using these projected emissions reductions (Table V) and assuming that a similar unit could be installed in Europe (included, for example, in the EU Emission Trading Scheme), 4 ktonne of avoided carbon-based emissions could alone be traded at $€ 48,000(\approx \$ 67,000) \mathrm{y}^{-1}$ (assuming an allowance of $€ 12\left[\mathrm{CO}_{2}\right]$ tonne $^{-1}$ ).

\section{MATHEMATICAL MODELLING AND SIMULATION}

Modelling and simulation could play important roles in the drive to develop and commercialise redox flow battery technologies. Extensive laboratory testing of different materials, components and additives over a broad range of conditions is both time-consuming and costly. In pilot studies, modelling can be used to systematically reduce the number of test cases and to analyse the results of tests and trials, as is already the case for fuel cells and static batteries. It can also provide valuable insight into the reaction environment at the cell level (details of the distributions of reactants, temperature, potentials and current density during operation) [96-99]. There is also 
Table V. Operational and environmental externalities reductions for the King Island $2500 \mathrm{~kW}$ wind farm/1100 kW flow battery system (augmenting a $6000 \mathrm{~kW}$ diesel engine generator). Modified from data provided by VRB Power Systems Inc. [73].

\begin{tabular}{llr}
\hline Operational factor & \multicolumn{1}{c}{ Quantity } & Annual value/\$ \\
\hline Cost reductions & & 91500 \\
Reduction of diesel spinning reserve operational time & $8 \mathrm{~h} \mathrm{~d}^{-1}$ & 83200 \\
Improved operational efficiency & $25 \mathrm{dm}^{3} \mathrm{~h}^{-1}$ (spinning reserve) & 51200 \\
Capture of 'spilled' wind power & $1100 \mathrm{~kW} \mathrm{~h} \mathrm{~d}^{-1}$ & 23000 \\
Maintenance reduction & 12 fewer generator set run-hours d & 248900 \\
& Total & - \\
Emissions reductions & & - \\
$\mathrm{CO}_{2}$ & $4 \mathrm{ktonne}^{-1}$ & - \\
$\mathrm{NO}_{x}$ & 99 tonne y & \\
Unburned hydrocarbons & 75 tonne y $^{-1}$ & \\
\hline
\end{tabular}

a need to develop simulation tools for the control and systematic optimization of stacks and whole systems.

Commercial interest in the zinc/bromine cell in the 1980s led to a number of attempts to model the system mathematically [100,101]. Despite this early activity, modelling of redox flow batteries is not a well-developed area, particularly in contrast to static batteries [96,97] and fuel cells $[98,99]$. The first models/simulations were based on severe simplifying assumptions (largely due to a lack of computational power), such as the confinement of variations in the reactant concentrations to thin diffusion layers adjacent to the electrode surfaces [100], onedimensional transport and neglect of electrolyte mixing in the external tanks $[100,101]$. At low rates of conversion per pass, these assumptions can be justified in some special cases but will otherwise lead to significant errors. Furthermore, such steady-state models are not capable of describing performance at different states of charge without further simplifying assumptions (e.g. negligible reservoir volumes [101]). A review of this early modelling work can be found in [102].

The emergence of new redox flow battery systems and a renewed commercial interest in the technologies could provide the impetus for further development of existing models, particularly among the academic community. This would depend, however, on the level of funding commitment from government agencies, commercial developers and end users. In the last decade, much of the funding for emerging energy technologies has been aligned towards fuel cells, despite the more immediate potential benefits of redox flow batteries. Shah and coworkers have developed detailed, physics-based models of the all-vanadium [103-106] and soluble lead-acid [107] cells using the conservation principles of charge, thermal energy, mass and momentum applied to a single cell and electrolyte tanks [103-106]. The multi-dimensional, dynamic equations were solved for a range of operating conditions (including temperature, mean electrolyte flow rate, initial reactant concentration) and validated against experimental data. The steady-state all-vanadium case was simulated by You et al. [108]. These studies provide detailed predictions of the reactant, current density and potential distributions within the electrodes, under the various operating conditions. The models can also be used to study the performance of unit cells using alternative component materials characterised by properties such as conductivity, electrode area and, in the case of porous electrodes, the porosity and pore diameter. Shah and co- $^{-}$ workers later extended their approach to include gasevolving reactions in the all-vanadium system and identify conditions under which these reactions could lead to as significant deterioration in performance $[105,106]$.

Scamman et al. investigated the performance of bromide/polysuphide redox flow battery systems using an equivalent-circuit approach in which the individual overpotential losses (ohmic, activation and concentration) were calculated using lumped parameter estimates $[109,110]$. A similar model was recently developed by Shah and co-workers for the all-vanadium system [111]. Although not able to capture the same level of detail at the unit cell scale as the models in [103-108], the equivalentcircuit approach is the ideal basis for control applications and stack/system-level modelling [112,113].

The models that have been developed can be improved in several respects and can be extended to other systems, for example, the zinc/cerium cell. There is scope to suggest improved cell designs with optimised chemistries, higher energy and power densities, and better thermal management. The electrolyte flow characteristics, which are vitally important, can be captured accurately using 3D models that represent the true geometries of the cells. Such 3D models would be particularly useful in developing strategies to provide an even distribution of reactants to the electrodes and prevent stagnant regions or highly stratified flows within the cells. A better characterisation of performance with respect to both operating conditions and material properties is possible using improved kinetic models.

Perhaps more importantly, there is an urgent requirement to develop and validate practical stack-level models to aid the design and optimisation of medium-scale and large-scale systems. These models must include sufficient detail of the mass, heat and charge transfer in individual cells and would ideally incorporate thermal and electrical 
coupling between the cells. Application devices and the auxiliary equipment can then be incorporated to develop comprehensive control and monitoring tools.

\section{BARRIERS TO TECHNOLOGY UPTAKE}

The primary barriers to increasing the rate of commercialisation of the all-vanadium battery are the capital costs associated with sourcing the electrolyte and manufacture of the battery stack, institutional barriers related to utility acceptance, planning, analysis skills and the perception of risk related to the absence of (1) universally accepted battery reliability estimates and (2) the true extent of the higher maintenance costs. Hall and Bain [11] also consider that health and safety have impacted upon the rate of RFB uptake because of the relatively toxic nature of most flow battery electrolytes, which would include the $\mathrm{H}_{2} \mathrm{SO}_{4}$-based electrolyte of the all-vanadium system.

Notwithstanding these issues, there is a significant potential market for energy storage which should increase through the first half of this century as fossil-fuel based energy conversion processes are replaced by the continued growth in renewable energy flow utilisation $[11,114,115]$. For the vanadium system, developments are already underway in the PRoC to reduce electrolyte costs [33] and electrode processes of RFBs have been improved to the point where system efficiencies of 70-80\% can be expected at the $\mathrm{kW}$ - to MW-scales (Table I). The role of established 'advanced' enclosed batteries, such as sodium-sulphur and lithium systems, is still unclear, although such systems are undergoing large-scale trials. It is likely that a mixture of energy storage technologies, for example, batteries (high energy density, low power density) and supercapacitors (high-power density, low-energy density) will have complementary roles in the future of the energy industry.

Policy-related barriers for flow-battery-based energy storage include the following:

1. A lack of multinational- and national-scale electricity utility-focused policy instruments specifically directing the uptake of energy storage via technologies such as $\mathrm{kW}$ - to MW-scale batteries, especially in Europe [6]

2. A disproportionately large number of environmentallyperverse subsidies, energy policies and legacies that continue to sustain fossil fuel-based electricity generation [116].

3. A lack of awareness of the importance and benefits of energy storage to the realisation of intermittent renewable energy and to finding efficiency savings from incumbent electricity generation methods.

4. A lack of showcase opportunities for the illustration of available energy storage systems and their relative merits.

5. Research funding policies that are heavily weighted towards flagship technologies such as fuel cells and lithium-ion batteries.
Environmentally polluting policies can be both economically and socially desirable [117] and such perverse incentives do not consider the costs of many (if any) of the environmental externalities. Above all other considerations, it may be assumed that simple economic cost estimates that exclude environmental externalities have probably led to an apparent lack of regulator, utility and operator acceptance of RFBs, which has reduced the potential for investment at the utility and distributed energy scales. The projected overall costs of renewables and batteries can be revised downwards by considering the potential growth in renewable power and by considering improved energy efficiency measures, together with an associated reduction in environmental insults [32]. The application of market-based (policy) instruments (MBIs) [113] could incorporate lead-in energy storage based government subsidies and investment tax credits (or tax reform) to more accurately price the externalities. The inclusion of energy storage technologies into national emissions trading schemes, such as the phase-three trading period of the EU ETS post 2012, would provide substantial economic benefit to battery developers.

\section{CONCLUSIONS}

For economic, domestic political, geopolitical and environmental reasons, there is an increasing demand for a reduction in the global use of fossil fuels, yet global energy consumption shows no sign of abating-in fact, it is forecast to increase significantly. It is critical, therefore, that existing energy resources are used much more efficiently through a combination of measures in which energy storage technologies should feature prominently (together with encouraging a change in attitudes and habits related to energy consumption through policy and education). It is also essential for governments to provide higher levels of financial and political backing for renewable energy technologies alongside other options such as nuclear power; political rhetoric has often not translated into real action.

Recent developments concerning the all-vanadium RFB technologies in Austria, Japan, China and Thailand reveal a significant level of battery commercialisation, namely with respect to electricity grid load levelling, utility-scale renewable electricity generation and distributed-energy/ remote-area power supply. The internal, operational and maintenance costs currently associated with the technology are important factors limiting uptake of this alternative form of spinning reserve. Although it is receiving some direct and indirect government support in many regions, fostering a market for emerging energy-storage technologies through an effective mix of regulation and marketbased policies would provide a much needed impetus for further improvements in the efficiency, durability and overall cost-competitiveness of this and other storage technologies [114]. The integration of renewable-energy and energy-storage technologies into the grid ought to be a 
consideration in the regulation of electricity supply and must be an integral part of the planning for future technology choices among the various options available. Environmental market-based instruments (tradable permits, subsidies, tax reform, etc.) could also be effective since the savings from avoided environmental externalities would make a combination of renewables and energy storage an attractive option compared with natural gas-fuelled spinning reserves [32]. Larger scale commercial systems and demonstration facilities to showcase vanadium redox flow battery technology should now be seen as essential to its adoption on a wider scale.

\section{ACKNOWLEDGEMENTS}

The authors are grateful for the helpful comments of Dr. Eric Martino (Institute for Sustainable Energy Policies, Japan). Helpful discussions with colleagues at the First International Flow Battery Forum, Vienna, 15-16 June 2010, have informed this paper.

\section{REFERENCES}

1. Schreiber M, Whitehead AH, Harrer M, Moser R. The vanadium battery-an energy storage reservoir for stand-alone ITS applications along motor-and expressways. Proceedings of 8th International IEEE Conference in Intelligent Transportation Systems, Vienna, Austria, 13-16 September 2006.

2. Shigematsu T, Kumamoto T, Deguchi H, Hara T. Application of a vanadium redox-flow battery to maintain power quality. Proceedings of Transmission and Distribution Conference and Exhibition 2002: Asia Pacific, Yokohama, Japan, 6-10 October 2002.

3. Skyllas-Kazacos M, Menictas C. The vanadium redox battery for emergency back-up applications. Proceedings of 19th International Telecommunications Energy Conference-INTELEC 1997, Melbourne, Australia, 19-23 October 1997.

4. Schaber C, Mazza P, Hammerschlag R. Utility-Scale Storage of Renewable Energy. Electricity Journal 2004; 17:21-29.

5. Ponce de León Albarran C, Frías-Ferrer A, GonzalezGarcia, J, Szánto DA, Walsh FC. Redox flow cells for energy conversion. Journal of Power Sources 2006; 160:716-732.

6. Verwijs H. Europe turns a blind eye to big battery. European Energy Review March 2009; 72-75.

7. Grimm V. Energy storage technologies - a way to cope with the intermittent supply of renewable energies. Proceedings of First International Renewable Energy Storage Conference (IRES I), Gelsenkirchen, Germany, 30-31 October 2006.
8. Prudent Energy - technology applications: city power, Prudent Energy Inc., China. (Available at: http://www. pdenergy.com/encity.html). Accessed on 18 April 2010.

9. Jossen A, Sauer DU. Advances in redox-flow batteries. Proceedings of First International Renewable Energy Storage Conference (IRES I), Gelsenkirchen, Germany, 30-31 October 2006.

10. VRB Power Systems Inc. The VRB energy storage system (VRB-ESSTM) - the multiple benefits of integrating the VRB-ESS with wind energy - case studies in MWH applications, Vancouver, Canada, 2007.

11. Hall PJ, Bain EJ. Energy-storage technologies and electricity generation. Energy Policy 2008; 36: 4352-4355.

12. Hope BK. An assessment of the global impact of anthropogenic vanadium. Biogeochemistry 1997; 37:1-13.

13. Rydh CJ. Environmental Assessment of Vanadium Redox and Lead-acid Batteries for Stationary Energy Storage. Journal of Power Sources 1999; 80:21-29.

14. Thaller LH. Patent: 3,996,064 Electrically rechargeable redox flow cell, USA, 1976.

15. Zito R. Patent: 4,485,154 Process for energy storage and/or power delivery with means for restoring electrolyte balance, USA, 1997.

16. Lim H-S, Lackner AM, Knechtli RC. Zinc-bromine secondary battery. Journal of The Electrochemical Society 1977; 124:1154-1157.

17. Plurion technology platform, Plurion Limited, Glenrothes, Fife. Available at: http://plurionsystems.com / tech_flow_technology.html. Accessed on 12 July 2009.

18. Pletcher D, Zhou H, Kear G, Low CTJ, Walsh FC, Wills RGA. A novel flow battery-a lead-acid battery based on an electrolyte with soluble lead(II) Part VI. Studies of the lead dioxide positive electrode. Journal of Power Sources 2008; 180:630 - 634.

19. Bartolozzi M. Development of redox flow batteries. A historical bibliography. Journal of Power Sources 1989; 27:219-234.

20. Menictas C, Hong DR, Yan ZH, Wilson M, Kazacos M, Skyllas-kazacos M. Status of the vanadium battery development program. Proceedings of Electrical Engineering Congress-EEC 94, Sydney, Australia, 24-29 November 1994.

21. Fabjan C, Garche J, Harrer B, Jorissen L, Kolbeck C, Philippi F, Tomazic G, Wagner F. The vanadium redox-battery: an efficient storage unit for photovoltaic systems. Electrochimica Acta 2001; 47:825 -831.

22. Kuntz MT, Dawe J. Renewable. Rechargeable. Remarkable. Mechanical engineering, New York ASME 2005; 127:35 -39. 
23. Joerissen L, Garche J, Fabjan C, Tomazic G. Possible use of vanadium redox-flow batteries for energy storage in small grids and stand-alone photovoltaic systems. Journal of Power Sources 2004; 127:98-104.

24. Huang KL, Li XG, Liu SQ, Tan N, Chen LQ. Research progress of vanadium redox flow battery for energy storage in China. Renewable Energy 2008; 33:186-192.

25. Hawkins JM, Robbins T.A vanadium energy storage field trial. Proceedings of Electrical Energy Storage Applications and Technologies (EESAT), San Francisco, USA, 15-17 April 2002.

26. Largent RL, Skyllas-Kazacos M, Chieng J. Improved PV system performance using vanadium batteries. Proceedings of Twenty Third IEEE Photovoltaic Specialists Conference, Louisville, KY, USA, 10-14 May 1993.

27. Utah Power cuts ribbon at pilot battery storage project, AllBusiness.com, Inc., San Francisco, USA. Available at: http://www.allbusiness.com/energyutilities/utilities-industry-electric-power/5585509-1. html. Accessed on 18 April 2010.

28. Nakayama Y, Takahashi S, Hirakawa, K, Yamaguchi Y. Development of a long life 35 Ah capacity VRLA battery for load-leveling applications. Journal of Power Sources 2004; 125:135-140.

29. Fang B, Wei Y, Arai T, Iwasa S, Kumagai M. Development of a novel redox flow battery for electricity storage system. Journal of Applied Electrochemistry 2003; 33:197-203.

30. Tokuda N, Kanno T, Hara T, Shigematsu T, Tsutsui Y, Ikeuchi A, Itou T, Kumamoto T. Development of redox flow battery system. SEI Technical Review 2000; 50:88-94.

31. Contact Energy signs peaking plant contracts, Thomson Reuters, New York, USA. Available at: http://www.reuters.com/article/rbssIndustryMaterials UtilitiesNews/idUSWLF00082820080415. Accessed on 18 April 2010.

32. Holdren JP, Smith KR. Chapter 3: energy, the environment, and health. In World Energy Assessment: Energy and the Challenge of Sustainability, Gururaja J (ed.). United Nations Development Programme, Bureau for Development Policy: New York, USA, 2000; 61-110.

33. Prudent Energy - technology applications: material, Prudent Energy Inc., Beijing, China. Available at: http://www.pdenergy.com/en/applications-solutions/ overview/overview.html. Accessed on 18 April 2010.

34. Skyllas-Kazacos M, Peng C, Cheng M. Evaluation of precipitation inhibitors for supersaturated vanadyl electrolytes for the vanadium redox battery. Electrochemical and Solid-State Letters 1999; 2:121-122.
35. Skyllas-Kazacos M. Patent: 6,143,443 Stabilised electrolyte solutions, methods of preparation thereof and redox cells and batteries containing stabilised electrolyte solutions, USA, 2000.

36. Skyllas-Kazacos M. Patent: PCT/AU02/00613 Vanadium redox battery electrolyte process, Australia, 2002.

37. Tanaka Y, Mita K, Horikawa K, Tokuda N, Furuya M, Kubata M. Patent: 2364550 Modified vanadium compound, producing method thereof, redox flow battery electrolyte composite and redox flow battery electrolyte producing method, Canada, 2002.

38. Broman BM. Patent: WO/2002/015317 Vanadium electrolyte preparation using asymmetric vanadium reduction cells and use of an asymmetric vanadium reduction cell for rebalancing the state of charge of the electrolytes of an operating vanadium redox battery, Switzerland, 2002.

39. Sukkar T, Skyllas-Kazacos M. Membrane stability studies for vanadium redox cell applications. Journal of Applied Electrochemistry 2004; 34:137-145.

40. Oei DG. Permeation of vanadium cations through anionic and cationic membranes. Journal of Applied Electrochemistry 1985; 15:231-235.

41. Mohammadi T, Skyllas-Kazacos M. Preparation of sulfonated composite membrane for vanadium redox flow battery applications. Journal of Membrane Science 1995; 107:35-45.

42. Qiu JY, Li MY, Ni JF, Zhai ML, Peng J, Xu L, Zhou HH, Li JQ, Wei GS. Preparation of ETFE-based Anion Exchange Membrane to Reduce Permeability of Vanadium Ions in Vanadium Redox Battery. Journal of Membrane Science 2007; 297:174-180.

43. Mohammadi T, Mahdifar M. Water transport study across commercial ion exchange membranes in the vanadium redox flow battery. Iranian Journal of Science and Technology 2001; 25:57-66.

44. Skyllas-Kazacos M, Rychcik M, Robins RG, Fane AG, Green MA. New all-vanadium redox flow cell. Journal of The Electrochemical Society 1986; 133:1057-1058.

45. Itoh T, Kanno T, Ikeuchi A, Kawai K, Hara T. Development of vanadium redox flow battery system. Proceedings of 34th Intersociety Energy Conversion Engineering Conference, Vancouver, Canada, 1-6 August 1999.

46. Linden D. Handbook of Batteries and Fuel Cells. McGraw Hill: New York, USA, 1984.

47. National Aeronautics and Space Administration (NASA). TM-83677, DOE/NASA/12726-24, NASA redox storage system development project, Houston, USA, 1984.

48. Codina G, Perez JR, Lopezatalaya M, Vazquez JL, Aldaz A. Development of a $0.1 \mathrm{~kW}$ power accumulation pilot plant based on an $\mathrm{Fe} / \mathrm{Cr}$ redox flow 
battery Part I. Considerations on flow-distribution design. Journal of Power Sources 1994; 48:293-302.

49. Walsh FC. Electrochemical technology for environmental treatment and clean energy conversion. Pure and Applied Chemistry 2001; 73:1819-1837.

50. Rychcik M, Skyllas-Kazacos M. Characteristics of a new all-vanadium redox flow battery. Journal of Power Sources 1988; 22:59-67.

51. Skyllas-Kazacos M, Kasherman D, Hong D-R, Kazacos M. Characteristics and performance of $1 \mathrm{~kW}$ UNSW vanadium redox battery. Journal of Power Sources 1991; 35:399-404.

52. Shibata AK, Sato K. Development of vanadium redox flow battery for electricity storage. Power Engineering Journal 1999; 13:130-135.

53. Vanadium redox-flow battery (VRB) for a variety of applications, Sumitomo Electric Industries Ltd.. Available at: http://electricitystorage.org/pubs/2001/ IEEE_PES_Summer2001/Miyake.pdf. Accessed on 18 April 2010.

54. The Cellennium (Thailand) Company Limited Technology - Basic Principle of the Vanadium Fuel Cell, Cellennium (Thailand) Company Limited, Bangkok. Available at: http://www.vanadiumbattery.com/technology. Accessed on 18 April 2010.

55. Shinzato T, Emura K, Yamanishi K, Deguchi H, Miyake S, Hara T, Suzuki K. Vanadium redox-flow battery for voltage sag. Proceedings of Electrical Energy Storage Applications and Technologies (EESAT), San Francisco, USA, 15-17 April 2002.

56. The vanadium redox flow battery - vanadium battery powered golf cart, University of New South Wales, Sydney. Available at: http://www.vrb.unsw.edu.au/. Accessed on 18 April 2010.

57. Zhao P, Zhang HM, Zhou HT, Chen J, Gao SJ, Yi BL. Characteristics and performance of $10 \mathrm{~kW}$ class allvanadium redox-flow battery stack. Journal of Power Sources 2006; 162:1416-1420.

58. VRB Power Inc. The VRB energy storage system (VRB-ESSTM) - an introduction to wind and the integration of a VRB-ESS, Vancouver, Canada, 2007.

59. Keefer RM. Patent: 3,682,704 Redox fuel cell regenerated with sugar, USA, 1972.

60. Toshio S, Yutaka H. Patent: JP60047373 Redox battery, Japan, 1985.

61. Skyllas-Kazacos M, Rychick M, Robins R. Patent: US 4,786,567 All-vanadium redox battery, USA, 1988.

62. Pellegri A, Spaziante PM. Patent: 2,030,349 Process and accumulator for storing and releasing electrical energy, UK, 1978.

63. Oei DG. Chemically regenerative redox fuel cells. Journal of Applied Electrochemistry 1982; 12:41-51.
64. Kummer JT, Oei DG. A chemically regenerative redox fuel cell. Journal of Applied Electrochemistry 1982; 12:87-100.

65. Kummer JT, Oei DG. A chemically regenerative redox fuel cell. II. Journal of Applied Electrochemistry 1985; 15:619-629.

66. Sum E, Skyllas-Kazacos M. A study of the V(II)/V (III) redox couple for redox flow cell applications. Journal of Power Sources 1985; 15:179-190.

67. Sum E, Rychcik M, Skyllas-Kazacos M. Investigation of the $\mathrm{V}(\mathrm{V}) / \mathrm{V}(\mathrm{IV})$ system for use in the positive half-cell of a redox battery. Journal of Power Sources 1985; 16:85-95.

68. Skyllas-Kazacos M, Rychick M, Robins R. Patent: AU575247B All vanadium redox battery, Australia, 1988.

69. Skyllas-Kazacos M, Kazacos G, Poon G, Verseema H. Recent advances with UNSW vanadium-based redox flow batteries. International Journal of Energy Research 2010; 34:182-189.

70. VRB power acquires Regenesys electricity storage technology \& announces USD \$2.8 million financing with RWE npower PLC, PR Newswire Europe Ltd., London. Available at: http://www.prnewswire.co.uk/ cgi/news/release $\mathrm{id}=130833$. Accessed on 18 April 2010.

71. VRB Power Systems Inc., VRB Power Systems Inc. VRB-EES sales brochure: the wind doesn't always blow when you need it, Vancouver, Canada, 2007.

72. Prudent Energy announces its assets acquisition of VRB Power Systems Inc., Prudent Energy Inc., Beijing, China. Available at: http://www.pdenergy. com/en/news_marketing/energy_storage_news/energy_storage_news_1.html. Accessed on 18 April 2010.

73. VRB Power Systems Inc. Remote area power systems: King Island, Vancouver, Canada, 2007.

74. The Cellennium (Thailand) Company Limited Announcements, Cellennium (Thailand) Company Limited, Bangkok. Available at: http://www. vanadiumbattery.com/news.html. Accessed on 18 April 2010.

75. Lu ZZ, Hu SL, Luo XL, Wu ZH, Chen LQ, Qiu XP. Effects of Proton Exchange Membranes on Performance of Vanadium Redox Flow Battery. Chemical Journal of Chinese Universities - Chinese 2007; 28:145-148.

76. Li XG, Huang KL, Liu SQ, Chen LQ. Electrochemical behavior of diverse vanadium ions at modified graphite felt electrode in sulphuric solution. Journal of Central South University of Technology 2007; 14:51-56.

77. Qian P, Zhang HM, Chen J, Wen YH, Luo QT, Liu ZH, You DJ, Yi BL. A novel electrode-bipolar 
plate assembly for vanadium redox flow battery applications. Journal of Power Sources 2008; 175:613-620.

78. Wen YH, Zhang HM, Qian P, Ma HP, Yi BL, Yang YS. Investigation on Concentrated V(IV)/V(V) Redox Reaction by Rotating Disc Voltammetry. Chinese Journal of Chemistry 2007; 25:278-283.

79. Wen YH, Zhang HM, Qian P, Zhao P, Zhou HT, Yi BL. Investigations on the Electrode Process of Concentrated V(IV)/V(V) Species in a Vanadium Redox Flow Battery. Acta Physico-Chimica Sinica 2006; 22:403-408.

80. Cellstrom GmbH. FB 10/100 (brochure), Brunn am Gebirge, Austria, 2009.

81. Cellstrom GmbH. Applications (brochure), Brunn am Gebirge, Austria, 2009.

82. Cellstrom - FAQ, Cellstrom GmbH, Brunn am Gebirge, Austria. Available at: http://www.cellstrom.at/FAQ. 4.0.html?\&L=1\#Q1. Accessed on 18 April 2010.

83. Press information-renewable energy fuel launched in London, Re-Fuel ESD, Corsham, UK. Available at: http://www.refueltec.com/refueltec_press_release. pdf. Accessed on 3 July 2009.

84. Size of VRB-ESS for Sorne Hill increased to $2 \mathrm{MW} \times 6 \mathrm{~h}$ and completion of Sustainable Energy Ireland / Tapbury feasibility study, PR Newswire Europe Ltd., London, UK. Available at: http://www. prnewswire.co.uk/cgi/news/release?id=193830. Accessed on 18 April 2010.

85. Sustainable Energy Ireland (SEI). Sustainable Energy Ireland, Dublin, Ireland. Available at: http://www. seai.ie/ /. Accessed on 18 April 2010.

86. Scandia National Laboratories. SAND2002-0751, Boulder City battery energy storage feasibility study, Albuquerque, USA, 2002.

87. ZBB Energy Corporation. ZBB (brochure), Wisconsin, USA, 2008.

88. Spaziante PM, Kampanatsanyakorn K, Zocchi A. Patent: WO 03/043170 A3 Redox flow battery system and method of operating it, Switzerland, 2003.

89. Announcements, Cellennium (Thailand) Company Limited, Bangkok, Thailand. Available at: http:// www.vanadiumbattery.com/news. Accessed on 18 April 2010.

90. Renewable Energy Policy Network for the 21st Century-REN21. Renewables global status report 2007, Paris, France, 2007.

91. VRB Power Systems - VRB-ESS technical specifications, VRB Power Systems Inc., Vancouver, Canada. Available at: http://www.vrbpower.com/technology/ ess-specifications.html. Accessed on 7 November 2008 (Historical - company web site superseded).
92. Kammen DM, Pacca S. Assessing the costs of electricity. Annual Review of Environment and Resources 2004; 29:301-344.

93. Fossil fuel electricity generating costs, Ministry of Economic Development, Wellington, NZ. Available at: http://www.med.govt.nz/templates/Multipage DocumentPage 10214.aspx. Accessed on 18 April 2010.

94. International Energy Agency. Experience curves for energy technology policy, Paris, France, 2000.

95. European Commission. EUR 20198, External costs -research results on socio-environmental damages due to electricity and transport, Brussels, Belgium, 2003.

96. Wang CY, Gu WB, Liaw BY. Micro-macroscopic coupled modeling of batteries and fuel cells. I. Model development. Journal of The Electrochemical Society 1998; 145:3407-3417.

97. Doyle M, Fuller TF, Newman J. Modeling of galvanostatic charge and discharge of the lithium/ polymer/insertion cell. Journal of The Electrochemical Society 1993; 140:1526-1533.

98. Shah AA, Ralph TR, Walsh FC. Modelling and simulation of the degradation of perfluorinated ionexchange membranes in PEM fuel cells. Journal of The Electrochemical Society 2009; 156:B465-B484.

99. Shah AA, Walsh FC. A model for hydrogen sulfide poisoning in proton exchange membrane fuel cells. Journal of Power Sources 2008; 185:287-301.

100. Lee J, Selman JR. Effects of Separator and Terminal on the Current Distribution in Parallel-Plate Electrochemical Flow Reactors. Journal of The Electrochemical Society 1982; 129:1670-1678.

101. Evans TI, White RE. A mathematical model of a zinc/bromine flow cell. Journal of The Electrochemical Society 1987; 134:866-874.

102. Evans TI, White RE. A review of mathematical modeling of the zinc/bromine flow cell and battery. Journal of The Electrochemical Society 1987; 134:2725-2733.

103. Shah AA, Watt-Smith MJ, Walsh FC. A dynamic performance model for redox-flow batteries involving soluble species. Electrochimica Acta 2008; 53:8087-8100.

104. Al-Fetlawi H, Shah AA, Walsh FC. Non-isothermal modelling of the all-vanadium redox flow battery. Electrochimica Acta 2009; 55:78-89.

105. Shah AA, Al-Fetlawi H, Walsh FC. Dynamic modelling of hydrogen evolution effects in the allvanadium redox flow battery. Electrochimica Acta 2010; 55:1125-1139.

106. Al-Fetlawi H, Shah AA, Walsh FC. Modelling the effects of oxygen evolution in the all-vanadium 
redox flow battery. Electrochimica Acta 2010; 55:3192-3205.

107. Shah AA, Li X, Wills RGA, Walsh FC. A mathematical model for the soluble lead-acid flow battery. Journal of The Electrochemical Society 2010; 157: A589-A599.

108. You D, Zhang HJ, Chen J. A simple model for the vanadium redox battery. Electrochimica Acta 2009; 54:6827-6836.

109. Scamman DP, Reade GW, Roberts EPL. Numerical modelling of a bromide-polysulphide redox flow battery. Part 1: Modelling approach and validation for a pilot scale system. Journal of Power Sources 2009; 189:1220-1230.

110. Scamman DP, Reade GW, Roberts EPL. Numerical modelling of a bromide-polysulphide redox flow battery. Part 2: Evaluation of a utility scale system. Journal of Power Sources 2009; 189:1231-1239.

111. Shah AA, Tangirala R, Singh R, Wills RGA, Walsh FC. A dynamic unit cell model for the all-vanadium flow battery. Journal of The Electrochemical Society 2011; doi: 10.1149/1.3561426.
112. Ben Salah C, Ouali M. Energy management of a hybrid photovoltaic system. International Journal of Energy Research 2010; doi: 10.1002/er.1765.

113. Martínez J, Morales A, Probst O, Llamas A, Rodríguez C. Analysis and simulation of a windelectric battery charging system. International Journal of Energy Research 2006; 30:633-646.

114. Hall PJ. Energy storage: The route to liberation from the fossil fuel economy? Energy Policy 2008; 36:4363-4367.

115. Renewable Environment Policy Network for the 21st Century-REN21. Renewables global status report -2009 update, Paris, France, 2009.

116. European Environment Agency. Energy subsidies in the European Union: a brief overview. EEA Technical report 1/2004, Copenhagen, Denmark, 2004.

117. European Environmental Agency. Using the market for cost-effective environmental policy-marketbased instruments in Europe. EEA Report No 1/ 2006, Copenhagen, Denmark, 2006. 